\title{
Can Ranchers Slow Climate Change?
}

\section{Carbon credits can be created on rangelands at costs that are competitive with credits from cropland and forestry, revealing that ranchers could play a role in reducing climate change.}

\author{
By Sara Campbell, Siân Mooney, John P. Hewlett, \\ Dale J. Menkhaus, and George F. Vance
}

0 everal state and federal efforts have been launched to reduce concentrations of carbon dioxide, methane, and nitrous oxide in the atmosphere because high concentrations of these "greenhouse" gases are thought to lead to global warming.

Ranchers can contribute to these efforts and create a new marketable commodity at the same time. Rangelands can be used to reduce atmospheric concentrations of carbon dioxide by increasing the rate at which rangeland soils store carbon. Some agricultural producers have been able to increase their income and diversify their income risk by selling this additional carbon to industries that emit large quantities of greenhouse gases [6]. The emerging market for environmental services could open new economic opportunities to range managers in the future.

\section{Rangelands \& Carbon}

There are approximately 524 million acres of private grazing lands in the U.S. with the potential to store an additional 60 million tons of carbon per year; equivalent to about five percent of the total U.S. emissions of carbon dioxide [3]. Although there is a large potential to store carbon within grassland and rangeland soils, the ability of ranchers to benefit economically will depend on whether they can increase carbon in these soils at a cost that is competitive with similar efforts from other sectors of the economy.

Little is known about the costs of sequestering carbon within rangeland soils. A budgeting approach can be used to examine the economic costs and the potential to create carbon credits. This technique is applied on a case study ranch in Wyoming. The costs of creating credits on this ranch can be compared to the costs of creating credits using other practices, such as forestry, to examine whether carbon storage in rangeland soils could compete economically in a national market for carbon credits. If this is the case then ranchers could be a part of the solution to slow global climate change.

\section{How can ranchers sell soil carbon?}

Markets, such as the Chicago Climate Exchange, are forming in the U.S. to buy and sell credits that help reduce atmospheric concentrations of greenhouse gases and reduce global warming. A carbon credit represents one ton of carbon that is stored in the soil and is equivalent to removing 3.67 tons of carbon dioxide from the atmosphere. If industries are required to reduce their net emissions of greenhouse gases, they can do this in two ways, either by cutting back on their own emissions or by purchasing credits from other sources. Companies will buy carbon credits created on rangelands if they are less costly than other methods they could adopt to reduce their emissions of greenhouse gases.

To date, only a few trades have taken place within the United States because there are a limited number of credit buyers within the existing voluntary market [8]. If emission limits are imposed in the future, more buyers will enter the market, which could provide new opportunities for ranchers to diversify their incomes and contribute to a solution for global warming. 
Carbon credits can be created by adopting range management practices that store carbon at faster rates than current practices. The difference between the original/base rate of carbon storage and the rate under a new management practice can be sold as credits.

For example, if the base management practice accumulated 0.1 tons of carbon per acre per year and under a change in management this increases to 0.4 tons of carbon per acre each year, 0.3 saleable credits are created on each acre. National guidelines for creating credits are not developed although many important considerations are discussed by the National Carbon Offset Coalition in a handbook they developed in 2002 [5].

How much will ranchers be paid for supplying credits to the market?

Because the market for credits is voluntary at present, there are not enough transactions to give good information about credit prices. However, ranchers will not produce credits unless the market price covers any costs they incur when they change management practices. If rangeland managers can create credits at a cost that is comparable or lower than credits created on cropland and forestry, then ranchers will be able to compete in any emerging market for credits.

\section{Management practices that create credits on grasslands}

We examine the economics of creating carbon credits on a 41,577 acre, cow/calf operation in central Wyoming (Fig. 1). The area is a temperate steppe mixed-grass ecosystem located at an elevation of 4,921 to 5,906 feet and receives between 11 to 14 inches of precipitation annually. Campbell reported in 2003 that the ranch supports $810-820$ total animal units on 21 separate pastures [2].

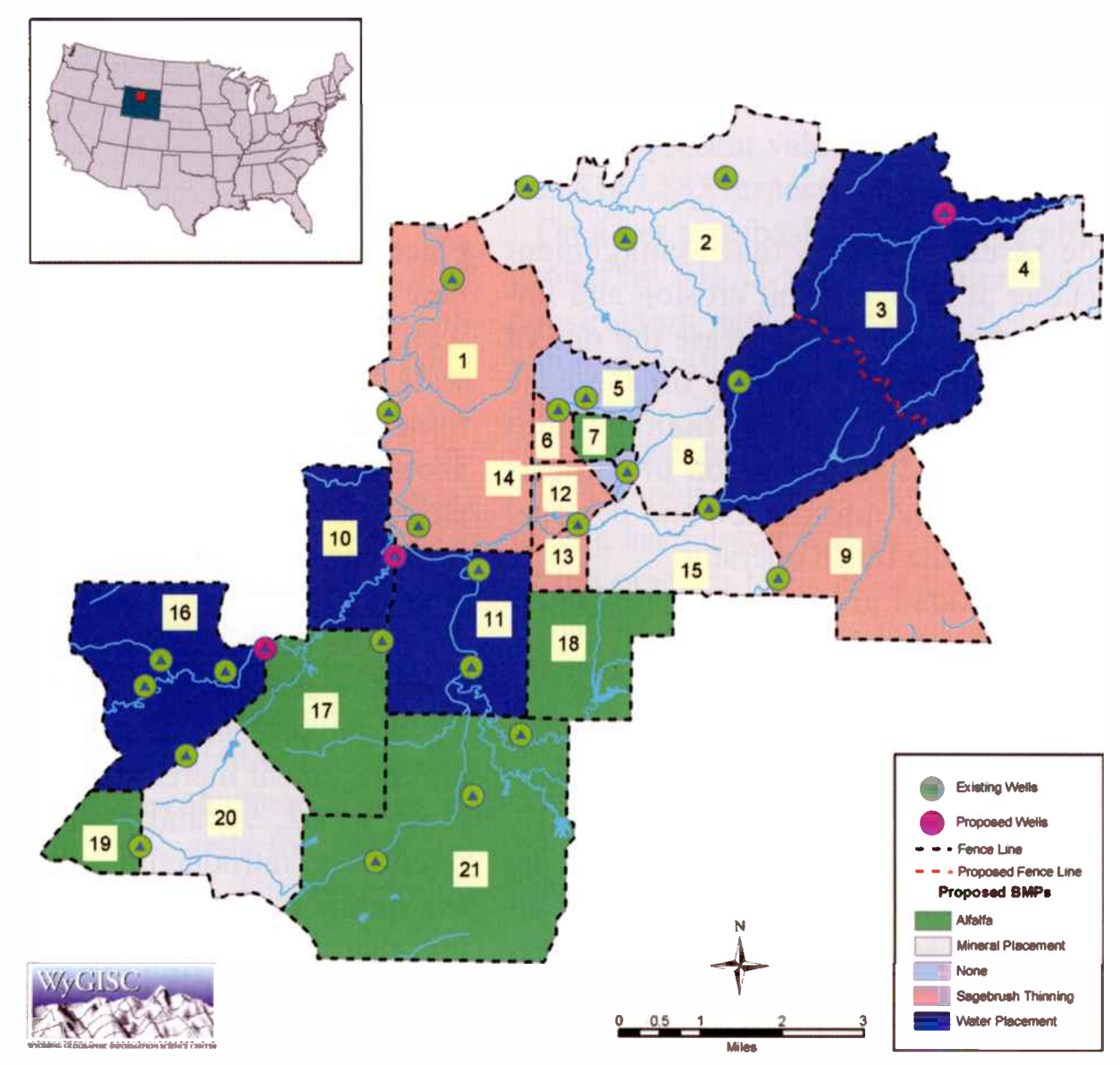

Fig. 1. Ranch Location, Pasture Configuration and Proposed Management Practices. 
Table 1. Forage Availability and Stocking Rate under Current and New Management Practices.

\begin{tabular}{|c|c|c|c|c|c|}
\hline & $\begin{array}{c}\text { Pastures } \\
\text { Shaded Green } \\
\left(9,680 \mathrm{ac}^{3}\right. \\
\text { treated })\end{array}$ & $\begin{array}{c}\text { Pastures } \\
\text { Shaded Light Blue } \\
(11,703 \mathrm{ac} \\
\text { treated })\end{array}$ & $\begin{array}{c}\text { Pastures } \\
\text { Shaded Brown } \\
(7,879 \text { ac } \\
\text { treated })\end{array}$ & $\begin{array}{c}\text { Pastures } \\
\text { Shaded Dark Blue } \\
(12,318 \mathrm{ac} \\
\text { treated })\end{array}$ & $\begin{array}{l}\text { All Pastures } \\
\text { (41,580 ac } \\
\text { treated) }\end{array}$ \\
\hline \multicolumn{6}{|c|}{ Current Practices } \\
\hline $\begin{array}{l}\text { Total Available } \\
\text { Forage }(\mathrm{M} \mathrm{lbs})^{\prime}\end{array}$ & 1.5 & 1.8 & 1.2 & 1.9 & 6.5 \\
\hline $\begin{array}{l}\text { Stocking Rate } \\
(\text { AUY })^{2}\end{array}$ & 188 & 227 & 153 & 240 & 808 \\
\hline \multicolumn{6}{|c|}{ New Management Practices } \\
\hline & Falcata Alfalfa & Mineral Placement & Thin Sagebrush & Water Placement & All Practices Combined \\
\hline Total Available & 2.4 & & & & \\
\hline Forage (M lbs) & 2.0 & 1.7 & 2.4 & 8.4 & \\
\hline $\begin{array}{l}\text { Stocking Rate } \\
\text { (AUY) }\end{array}$ & 296 & 245 & 207 & 302 & 1050 \\
\hline $\begin{array}{l}\text { Change in AUYs per } \\
100 \text { acres } \\
\text { treated (AUY) }\end{array}$ & 1.12 & 0.15 & 0.69 & 0.50 & 0.58 \\
\hline $\begin{array}{l}\text { Change in } \\
\text { Stocking Rate } \\
\text { from Current } \\
\text { Practices (AUY) }\end{array}$ & 108 & 18 & 54 & 62 & 242 \\
\hline
\end{tabular}

Soil science research shows that management practices effective at reducing soil erosion and improving range productivity also increase the rate of soil carbon accumulation. Pastures on the case study ranch that are suitable for management changes that increase the accumulation of soil carbon were identified using information and personal judgment supplied by the ranch operator.

On the pastures shaded green the costs of interseeding falcata alfalfa (Medicago sativa ssp. falcata) with native grasses are examined (Fig. 1). This practice increases the rate of carbon accumulation on each acre by 0.18 to 0.27 tons per year compared to existing management $[4,9]$.

On pastures shaded light blue the cost of placing additional mineral blocks during the summer to attract cattle away from sensitive grazing areas is examined.

On the areas shaded brown sagebrush thinning is considered. Finally, a geographical information system analysis was undertaken to identify areas that lacked access to well water, resulting in new wells placed in pastures shaded blue and in one area a new fence was used to improve water use. The new wells will reduce the distance that cattle have to walk for water. These three practices, additional mineral placement, sagebrush thinning and closer access to water, are assumed to increase the rate of carbon storage on each acre by between 0.05 to 0.13 tons per year based on the results of previous studies [9].

All the practices increased the quantity of forage available and the stocking rate of the ranch (Table 1). Water placement, sagebrush thinning, and mineral placement increase the carrying capacity of the ranch by 62,54 , and 18 animal unit years ${ }^{2}$ respectively. The introduction of falcata alfalfa increases the number of animal unit years by 108 , slightly less than the combined effect of the other management practices. If the suggested management prac-

\footnotetext{
Based on the assumption that each cow demands $8,047 \mathrm{lbs}$ of forage per year [2].

${ }^{2} \mathrm{An}$ animal unit is the amount of forage required to support a single cow for one year.
} 
Table 2. Present Value of Reduced Profits ${ }^{1}$ over 20 Years by New Management Practice

\begin{tabular}{|c|c|c|c|c|c|}
\hline $\begin{array}{l}\text { Management } \\
\text { Practice }\end{array}$ & $\begin{array}{c}\text { Falcata Alfalfa } \\
\left(9,680 \mathrm{ac}^{2}\right. \\
\text { treated })\end{array}$ & $\begin{array}{c}\text { Mineral } \\
\text { Placement } \\
(11,703 \text { ac treated })\end{array}$ & $\begin{array}{c}\text { Thin Sagebrush } \\
(7,879 \text { ac } \\
\text { treated })\end{array}$ & $\begin{array}{c}\text { Water } \\
\text { Placement } \\
(12,318 \text { ac treated })\end{array}$ & $\begin{array}{c}\text { All Practices } \\
\text { Combined } \\
(41,580 \text { ac treated })\end{array}$ \\
\hline $\begin{array}{l}\text { Difference in } \\
\text { Present Value } \\
\text { of Ranch Profit } \\
\left(\$ \$^{\circ} 000\right)\end{array}$ & 437 & 148 & 204 & 255 & 1,072 \\
\hline $\begin{array}{l}\text { Difference in Present } \\
\text { Value of Profit per } \\
\text { Acre Treated }(\$)\end{array}$ & 45.1 & 12.6 & 25.9 & 20.7 & 25.8 \\
\hline
\end{tabular}

${ }_{2}$ Calculated as the present value of current management maintained over twenty years minus the present value of adopting an alternative practice over twenty years.

$\mathrm{ac}=\mathrm{acres}$

tices are introduced simultaneously we estimate that the stocking capacity of the case study ranch will increase by 242 animal unit years.

On a per-acre basis, interseeding falcata alfalfa has the greatest influence on stocking rate, followed by sagebrush thinning, and water and mineral placement. If all practices are implemented at the same time, the stocking rate increases by 0.6 animal unit years per one hundred acres, an increase of almost 30 percent.

\section{Calculating the cost}

\section{of each management practice}

The change in ranch profitability as a result of adopting each new management practice can be calculated using two steps. First, the results from Table 1 can be used to estimate the expected change in the ranch's annual profits assuming that the rancher increases the stocking rate to utilize the additional available forage.

In this step, the change in revenue associated with selling a larger number of animals as well as any change in input costs such as feed, for keeping a larger herd can be estimated. In the second step, the probable size and timing of any additional costs that are incurred by the rancher are calculated. These include, the cost of drilling new wells for water and purchasing additional stock tanks. The assumption is that the rancher enters into a contract to produce carbon credits over a period of 20 years ${ }^{3}$ and that all management and capital improvements are imple-

${ }^{3}$ The ability to sequester additional soil carbon tends to decrease after about twenty years. mented in the first year of the contract and will have a useful life of 20 years. Implementation costs are spread equally over each year.

The change in the net present value of ranch profits due to adopting each practice over 20 years is shown in Table 2. The largest decrease in the present value of profits $(\$ 436,632)$ occurs from interseeding alfalfa. The provision of water wells reduces ranch profits by $\$ 255,344$ over 20 years, while sagebrush thinning and mineral placement reduce the present value of ranch profits by $\$ 204,408$ and $\$ 147,585$ respectively.

On a per acre basis, interseeding alfalfa decreases profits by $\$ 45.11$ per-acre while thinning sage and constructing new water wells decrease the present value of profits per-acre by $\$ 25.94$ and $\$ 20.73$, respectively. Mineral placement is the least costly practice per-acre, costing $\$ 12.60$.

It is important to understand that the cost of producing each credit will be determined by the ability of the practice to increase the rate of carbon accumulation as well as the economic costs. It is possible that the practice with the highest total costs also has the greatest ability to create the largest number of credits and so although total costs are high, the cost per credit could be low, enabling the rancher to be competitive at selling credits to reduce atmospheric concentrations of greenhouse gases.

\section{At what price would the ranch sell credits?}

The case study rancher will not create carbon credits unless their market price is high enough to cover the cost of producing them. The cost per credit is a combination of two factors: how much 


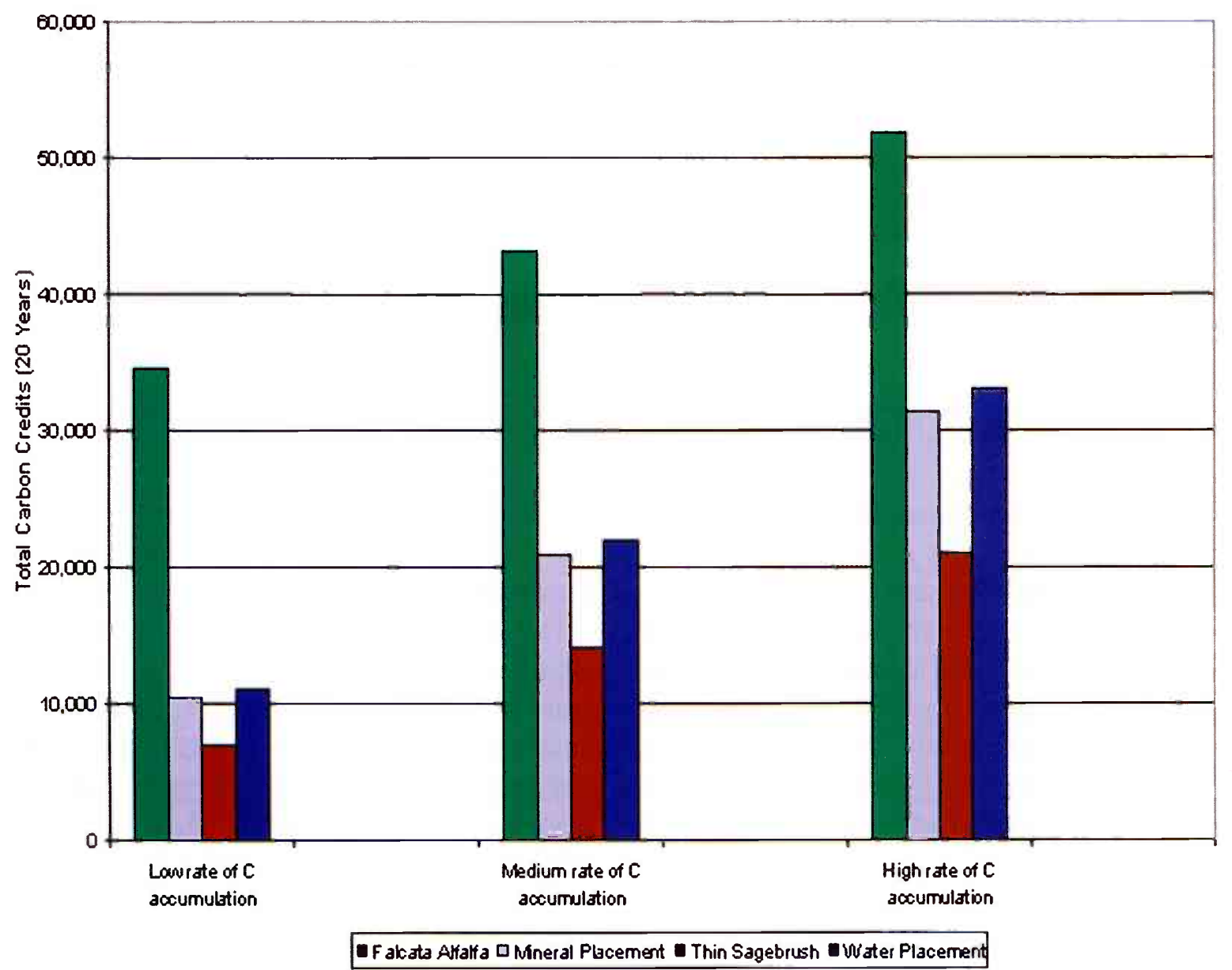

Fig. 2. Total Carbon Credits Created over Twenty Years Assuming Low ${ }^{1}$, Medium ${ }^{2}$ and High Rates of Carbon Accumulation.

carbon can be produced and stored on each acre by changing management practices (Fig. 2) and the costs of changing pasture management (Table 2). The total number of credits created over 20 years is shown in Figure 2 assuming low, medium and high rates of carbon accumulation.

Of the four individual practices, planting alfalfa shows the largest increase in carbon, ranging from 34,559 to 51,838 tons of carbon over 20 years. Sagebrush thinning gives the smallest total gains in carbon, ranging between 7,032 and 21,098 tons (Fig. 2).

The average costs of producing marketable credits using each practice are shown in Table 3 and range between a low of $\$ 4.17$ per-credit for mineral placement to a high of $\$ 29.07$ per-credit for sagebrush thinning. At low rates of carbon accumulation, interseeding alfalfa generates carbon for the lowest cost per-credit. However at higher rates of carbon
${ }^{1}$ Assuming that provision of additional mineral supplements, sagebrush thinning and provision of additional water wells increase the rate of carbon stored by 0.05 tons per-acre per-year for 20 years. Interseeding of falcata alfal$\mathrm{fa}$ is assumed to increase the rate of carbon stored by 0.18 tons per-acre per-year.

${ }^{2}$ Assuming that provision of additional mineral supplements, sagebrush thinning and provision of additional water wells increase the rate of carbon stored by 0.09 tons per-acre per-year for 20 years. Interseeding of falcata alfal$\mathrm{fa}$ is assumed to increase the rate of carbon stored by 0.22 tons per-acre per-year.

${ }^{2}$ Assuming that provision of additional mineral supplements, sagebrush thinning and provision of additional water wells increase the rate of carbon stored by 0.13 tons per-acre per-year for 20 years. Interseeding of falcata alfal$\mathrm{fa}$ is assumed to increase the rate of carbon stored by 0.27 tons per-acre per-year. 
Table 3. Average Cost ${ }^{1}$ of Producing each Carbon Credit

\begin{tabular}{|c|c|c|c|c|c|}
\hline $\begin{array}{l}\text { Management } \\
\text { Practice }\end{array}$ & $\begin{array}{l}\text { Falcata } \\
\text { Alfalfa }\end{array}$ & $\begin{array}{c}\text { Mineral } \\
\text { Placement }\end{array}$ & $\begin{array}{c}\text { Thin } \\
\text { Sagebrush }\end{array}$ & $\begin{array}{c}\text { Water } \\
\text { Placement }\end{array}$ & $\begin{array}{l}\text { All Practices } \\
\text { Combined }\end{array}$ \\
\hline \multicolumn{6}{|c|}{ Cost per credit (\$) } \\
\hline $\begin{array}{l}\text { Low rate of carbon } \\
\text { accumulation }^{2}\end{array}$ & 12.6 & 14.1 & 29.0 & 23.2 & 17.0 \\
\hline $\begin{array}{l}\text { Medium rate of } \\
\text { carbon accumulation }^{3}\end{array}$ & 10.1 & 7.0 & 14.5 & 11.6 & 10.7 \\
\hline $\begin{array}{l}\text { High rate of carbon } \\
\text { accumulation }^{3}\end{array}$ & 8.4 & $\overline{4.7}$ & 9.6 & 7.7 & 7.8 \\
\hline \multicolumn{6}{|c|}{$\begin{array}{l}\text { Present value of average cost }=(\text { Present value current management over } 20 \text { years - Present value of new management over } 20 \text { years }) / \text { Total number of carbon credits cre- } \\
\text { ated over } 20 \text { years. } \\
2 \text { Assuming that provision of additional mineral supplements, sagebrush thinning and provision of additional water wells increase the rate of carbon stored by } 0.05 \text { tons } \\
\text { per-acre per-year for } 20 \text { years. Interseeding of falcata alfalfa is assumed to increase the rate of carbon stored by } 0.18 \text { tons per-acre per-year. } \\
3 \text { Assuming that provision of additional mineral supplements, sagebrush thinning and provision of additional water wells increase the rate of carbon stored by } 0.09 \text { tons } \\
\text { per-acre per-year for } 20 \text { years. Interseeding of falcata alfalfa is assumed to increase the rate of carbon stored by } 0.22 \text { tons per-acre per-year. } \\
\text { Assuming that provision of additional mineral supplements, sagebrush thinning and provision of additional water wells increase the rate of carbon stored by } 0.13 \text { tons } \\
\text { per-acre per-year for } 20 \text { years. Interseeding of falcata alfalfa is assumed to increase the rate of carbon stored by } 0.27 \text { tons per-acre per-year. }\end{array}$} \\
\hline
\end{tabular}

accumulation, mineral and water placement become the lowest cost options per-credit. These results highlight that it is important to account for the number of credits that can be generated by a practice as well as the cost of implementing that practice. In every scenario, sagebrush thinning produces credits for the greatest cost and on this ranch is the least efficient way to produce carbon. If all practices were implemented simultaneously, the average cost percredit ranges between $\$ 7.81$ to $\$ 17.01$.

The costs calculated for the Wyoming ranch suggest that carbon credits can be produced on rangeland soils at costs that compete with credits from cropland and forestry. For example, a 2003 study of Montana dryland crop systems estimated that carbon credits can be produced for as little as $\$ 9$ [1]. A similar study showed that, in Iowa, credits can be produced for as little as $\$ 12$ if producers switch from conventional to no-till practices [7]. Similarly, shifting marginal agricultural land to forested use can produce credits at costs ranging from one dollar and up, depending on the quantity produced.

\section{Can ranchers slow climate change?}

Based on the numbers above, the case study rancher could compete against cropland and forestry in a market for carbon credits and could contribute to environmental stewardship efforts. In addition, by participating in the fight to reduce global warming the rancher has an opportunity to increase enterprise diversity as well as increase ranch income.
There are several other opportunities that the rancher could use to lower costs even further. In a 2003 study of this Wyoming ranch, Campbell showed that if the rancher enrolled in the Environmental Quality Incentives Program, the cost of producing carbon credits could be reduced by an additional 10 to 40 percent [2]. Getting to the bottom line, ranchers can likely compete in the new emerging market for carbon credits and provide a part of the solution for global climate change, benefiting both their immediate income as well as protecting our nation's resources and environment for future generations. It's a win-win opportunity.

Acknowledgements: This material is based upon work supported by the Cooperative State Research, Education and Extension Service, US Department of Agriculture, under agreement Nos. 2003-35400-12907 and 2001-38700-1192 and the University of Wyoming Agricultural Experiment Station. All error's and omissions are the authors'.

About the Authors: Sara Campbell is a former MS student, Department of Agricultural and Applied Economics, University of Wyoming, Laramie, Wyoming 82071; Siân Mooney is an Assistant Professor, Department of Agricultural and Applied Economics, University of Wyoming, Laramie, Wyoming 82071; John Hewlett is a Farm Management Specialist, Department of Agricultural and Applied Economics, University of Wyoming, Laramie, Wyoming 82071; Dale Menkhaus is a Professor, Department of Agricultural and Applied Economics, University of Wyoming, Laramie, Wyoming 82071; and George Vance is the J. E. Warren Distinguished Professor of Energy and Environment, Department of Renewable Resources, University of Wyoming, Laramie, Wyoming 82071. 


\section{References}

1. Antle, J., S. Capalbo, S. Mooney, E. Elliot, and K. Paustian. 2003. Spatial Heterogeneity and the Design of Efficient Carbon Sequestration Policies for Agriculture. Journal of Environmental Economics and Management. 46(2):231-250.

2. Campbell, S. 2003. Economics of Rangeland Carbon Sequestration: A Wyoming Ranch Study. M.S. Thesis, Department of Agricultural and Applied Economics, University of Wyoming, Laramie, Wyoming 82071.

3. Follett R.F, J.M. Kimble, and R. Lal. 2001. The Potential of U.S. Grazing Lands to Sequester Carbon and Mitigate the Greenhouse Effect. Boca Raton: Lewis Publishers, CRC Press.

4. Mortenson, M. 2003. Effects of Interseeding Alfalfa (Medicago sativa spp. falcata) on Forage Production, Forage Quality and Carbon Sequestration on a MixedGrass Rangeland. M.S. Thesis, Department of Renewable Resources, University of Wyoming, Laramie, Wyoming 82071.
5. National Carbon Offset Coalition. 2002. Project Planning Handbook: Forestry Project to Create Carbon Sequestration Units (CSU's). Version 1.0. Available from www.carbonoffsetcoalition.org.

6. Pacific Northwest Direct Seed Association. 2002. A Synopsis of the PNDSA Soil Carbon Sequestration Lease Contract: History in the making. http://www.directseed.org/Articles/arbon_synopsis.htm

7. Pautsch, G.R., L.A. Kurkalova, B. Babcock, and C.L. Kling. 2001. The efficiency of sequestering carbon in agricultural soils. Contemporary Economic Policy. 19(2):123-134.8.

8. Rosenzweig, R., M. Varilek, B. Feldman, R. Kuppalli, and J. Janssen. 2002. The Emerging International Greenhouse Gas Market. Pew Center for Global Climate Change, Arlington Virginia.

9. Schuman G., J. Herrick, and H. Janzen. 2001. The Dynamics of Soil Carbon in Rangelands. In R. Follett, J. Kimble, R. Lal (Eds.) Potential of U.S. Grazing Lands to Sequester Carbon and Mitigate the Greenhouse Effect. Boca Raton: Lewis Publishers, pp:267-290. 